Journal of Agricultural Sciences
(Tarim Bilimleri Dergisi)

\title{
Impact of Hot Water and Modified Atmosphere Packaging Treatments on the Postharvest Quality of Pomegranate Fruit (Punica granatum cv. 'Hicaznar')
}

\author{
Ahmet Erhan ÖZDEMIR ${ }^{\mathrm{a}}\left(\mathbb{D}\right.$, Elif ÇANDIR ${ }^{\mathrm{a} *}$ (i) \\ ${ }^{a}$ Hatay Mustafa Kemal University, Department of Horticulture, Antakya, Hatay, TURKEY \\ ARTICLE INFO \\ Research Article \\ Corresponding Author: Elif ÇANDIR, E-mail: elif.1026@hotmail.com \\ Received: 19 December 2019, Revised: 20 March 2020, Accepted: 26 March 2020 / Online: 04 September 2021
}

\section{ABSTRACT}

Hot water (HW) and modified atmosphere packaging (MAP) treatments were evaluated to maintain postharvest quality of pomegranate fruit (Punica granatum cv. 'Hicaznar'). Pomegranates were subjected to hot water (HW) treatment (at $50^{\circ} \mathrm{C}$ for $3 \mathrm{~min}$ ) and packaged with or withou MAP bags. Fruit was then kept at $6{ }^{\circ} \mathrm{C}$ for 6 months and at $20{ }^{\circ} \mathrm{C}$ for 7 days after cold storage period. The untreated and unpackaged fruit was served as a control treatment (C). MAP and HW+MAP treatments was more effective in reducing weight loss, fungal decay and husk scald, compared to $\mathrm{HW}$ and $\mathrm{C}$ treatments. The lightness and red color intensity of husk and aril (higher values of $\mathrm{L}^{*}$ and $\mathrm{C}^{*}$ and lower values of $\mathrm{h}^{\circ}$ ) were maintained better in the packaged fruit with MAP (MAP + HW+MAP treatments). The unpackaged fruit from $\mathrm{HW}$ and $\mathrm{C}$ treatments became unmarketable while those from MAP and HW+MAP treatments were still marketable after 6 months of cold storage and shelf life period. Although fungal decay incidence was low in HW-treated fruit, relatively high scald incidence and weight loss had adverse effect on overall visual acceptability of HW-treated fruit. Hot water dipped pomegranate fruit $\mathrm{cv}$. 'Hicaznar' $\left(50{ }^{\circ} \mathrm{C}\right.$ for $\left.3 \mathrm{~min}\right)$ could be kept in MAP bags for 6 months at $6{ }^{\circ} \mathrm{C}$ and for 7 days $20^{\circ} \mathrm{C}$ without adverse effect on quality.

Keywords: MAP, Shelf life, Cold storage, Chilling injury, Husk scald

(C) Ankara University, Faculty of Agriculture

\section{Introduction}

Pomegranate (Punica granatum L.) production and export of Turkey has been reached over 500 thousand tons and 200 thousand tons, respectively (TSI 2018). 'Hicaznar' is the dominated cultivar and produced in mostly the Mediterranean and Aegean regions. Major destination markets of Turkish pomegranate export are the European Union countries beside to Russian Federation and other Middle East countries. Commercial storage of pomegranates is advised to prolong until late March (Selçuk \& Erkan 2015) when price of pomegranate fruit in European markets reaches the highest level (Rymon 2012). Postharvest quality of pomegranate fruit is often impaired by the visible shriveling symptoms, chilling injury, husk scald, fungal decay beside to deterioration in aril color and taste of pomegranate fruit during long-term cold storage (D'Aquino et al. 2010; Selçuk \& Erkan 2015; Porat et al. 2016; Candir et al. 2018; 2019).

Postharvest heat treatments such as curing, intermittent warming and hot water (HW) dips $\left(45^{\circ} \mathrm{C}\right.$ to $55^{\circ} \mathrm{C}$ for 1 to 5 min) have been studied to reduce chilling injury and fungal decay and improve nutritive and functional properties of pomegranates (Artés et al. 2000a; Mirdehghan \& Rahemi 2005; Mirdehghan et al. 2006; 2007; Ramezanian \& Rahemi 2010; Moradinezhad \& Khayyat 2014). Modified atmosphere packaging (MAP) has been reported to be effective in maintaining the external and internal quality of pomegranate fruit by controlling weight loss, fungal decay and husk scald, and during cold storage period (Artés et al. 2000b; Nanda et al. 2001; D’Aquino et al. 2010; Selçuk \& Erkan 2014; 2015; Porat et al. 2016). Combination of hot water, salicylic acid and MAP were reported to be more effective in reducing decay and chilling injury of pomegranate fruit cv. 'Sheshi-kab' in compared to individual application of each treatment (Moradinezhad et al. 2013). In this study, we investigated the combined effects of HW and MAP treatments on postharvest quality characteristics of pomegranate fruit cv. 'Hicaznar' during cold storage and shelf life period.

\section{Material and Methods}

Pomegranates (cv. 'Hicaznar') were taken from the local commercial orchard where the trees were planted at $5 \mathrm{~m} \times 5 \mathrm{~m}$ spacing and were 9-year-old. Fertilizers (160 kg N ha $\mathrm{kg}^{-1}, 80 \mathrm{~kg} \mathrm{P}_{2} \mathrm{O}_{5} \mathrm{ha}^{-1}$, and $140 \mathrm{~kg} \mathrm{~K}_{2} \mathrm{O}$ ha ${ }^{-1}$ ) were applied under drip irrigation system. The orchard with loamy-clayey and slightly alkaline of soil was located in Antakya-Hatay in the Eastern Mediterranean region of Turkey $\left(36^{\circ} 12^{\prime} 59^{\prime \prime} \mathrm{N}, 36^{\circ} 25^{\prime} 43^{\prime \prime} \mathrm{E}\right.$, at altitude of $\left.88 \mathrm{~m}\right)$. The typical Mediterranean climate prevails 
in this region with annual $1.126 \mathrm{~mm}$ precipitation, $69 \%$ average annual relative air humidity and annual average temperatures ranged from $8.2^{\circ} \mathrm{C}$ to $27.7^{\circ} \mathrm{C}$.

Fruit was hand-harvested when titratable acidity (TA) and soluble solids content (SSC) were <1.85\% and >17\%, respectively during the 2015-2016 season and were then immediately transported to the storage and laboratory facilities of the Horticultural Department at Hatay Mustafa Kemal University. Pomegranate fruit in uniform size and maturity without defects and blemishes was subjected to the following treatments: (1) Fruit was dipped in hot water (at $50{ }^{\circ} \mathrm{C}$ for 3 min) and stored in $52 \times 36 \times 30 \mathrm{~cm}$ plastic boxes (HW); (2) fruit dipped in hot water was packaged with MAP (HW+MAP); (3) fruit without hot water dip was packaged in modified atmosphere packages (MAP); (4) fruit was dipped in water at $24{ }^{\circ} \mathrm{C}$ for 3 min and stored in plastic boxes (W) and (5) Control fruit without HW and MAP treatments was stored in plastic boxes (C). Hot water dip temperature was chosen according to the findings of previous studies conducted on 'Hicaznar' and 'Sheshi-kab' pomegranate cultivars (Kipri \& Dündar 2011; Moradinezhad \& Khayyat 2014). In MAP and HW+MAP treatments, the 5 kg Life Pack ${ }^{\circledR}$ (Patent No.: 2007 45625, Aypek Ambalaj Co., Bursa) bags were used as MAP. The HW and W treated fruits were allowed to dry on a paper towel at room temperature for 1 hour before packaging and storage. Packaged fruits were cooled to $6{ }^{\circ} \mathrm{C}$ for 24 hours before sealing the MAP bags and then stored together with the fruits from other treatments at $6 \pm 0.5{ }^{\circ} \mathrm{C}$ and $90 \pm 5 \% \mathrm{RH}$ for 6 months. Fruit was also kept at $20 \pm 1{ }^{\circ} \mathrm{C}$ and $70 \pm 5 \%$ relative humidity for 7 days after 2,4 and 6 months of cold storage period.

Postharvest quality was evaluated by two months intervals. Weight loss was determined as percentage by weighting of each fruit at harvest and after every 2 months. Check Point model $\mathrm{O}_{2} / \mathrm{CO}_{2}$ analyzer (PBI-Dansensor America Inc., NJ) was used to monitor headspace $\mathrm{O}_{2}$ and $\mathrm{CO}_{2}$ concentration of the bags. Husk color was measured at three points on the equatorial region of each individual fruit using the CIE L*a*b* color space with a CR-300 Minolta Chroma Meter (Osaka, Japan). Arils color was determined according to Artés et al. (1998). Chroma $\left(C^{*}\right)$ values were calculated as $C^{*}=\left(a^{* 2}+b^{* 2}\right)^{1 / 2}$ and hue angle values as $\left(h^{\circ}\right) h^{\circ}=\tan ^{-1}\left(b^{*} / a^{*}\right)$. The juice was obtained by squeezing of arils of five fruit per replicate through cheesecloth with hand press and used to determined total soluble solids (TSS) content and titratable acidity (TA). The TSS content was measured using a Atago Model ATC-1E refractometer. The five $\mathrm{mL}$ of juice was titrated with $0.1 \mathrm{~N} \mathrm{NaOH}$ to a $\mathrm{pH}$ of 8.1 to determine TA (citric acid equivalents). The panelists evaluated overall visual quality using a 5 point scale, where: $1=$ very poor; $2=$ poor (limit of marketability); 3= good; 4= very good; 5=excellent (Selçuk \& Erkan 2015), and taste using a hedonic scale , where $1=$ disliked to $9=$ liked. The fruit was examined visually for fungal decay and chilling injury and husk scald symptoms according to Defilippi et al. (2006). Fungal decay and scald incidence was calculated as a percentage of the fruit affected by decay or and scald. Severity of scald was assessed using a 6 point scale, where $1=$ no scald, $2=<10 \%, 3=11-250 \%, 4=25-$ $50 \%, 5=50-75$ and $6=75-100 \%$ of the surface affected.

The data were analyzed using SAS software (SAS 2019) according to a completely randomized design with five treatments, and three replications for each treatment. Each replication contained the $5 \mathrm{~kg}$ of fruit. Fisher's least significant difference (LSD) test was performed at a $\mathrm{P}<0.05$ level for mean separation using the SAS Proc GLM procedure.

\section{Results and Discussion}

\subsection{Headspace $\mathrm{O}_{2}$ and $\mathrm{CO}_{2}$ concentration}

Figure 1a and $1 \mathrm{~b}$ presents changes in $\mathrm{O}_{2}$ and $\mathrm{CO}_{2}$ concentrations, respectively, inside the MAP bags. Effects of treatments $\times$ storage period interaction on the changes in headspace $\mathrm{O}_{2}$ and $\mathrm{CO}_{2}$ concentration were significant $(\mathrm{P}<0.05)$. In both treatments, except for a slight increase in $\mathrm{O}_{2}$ concentration and a slight decrease in $\mathrm{CO}_{2}$ concentration after 4 months, $\mathrm{O}_{2}$ concentrations inside MAP decreased while $\mathrm{CO}_{2}$ concentration increased during cold storage period. After 6 months of cold storage, final headspace $\mathrm{O}_{2}$ and $\mathrm{CO}_{2}$ levels were $15.30 \%$ and $7.77 \%$ in MAP treatment and $16.73 \%$ and $6.57 \%$ in $\mathrm{HW}+\mathrm{MAP}$ treatment, respectively. MAP treatment resulted in a lower $\mathrm{O}_{2}$ and a higher $\mathrm{CO}_{2}$ levels than $\mathrm{HW}+\mathrm{MAP}$ treatment during cold storage. The MAP bag tested in this study ensured a proper modified atmosphere for pomegranate fruit cv. 'Hicaznar' since previous studies suggested 13.50-17.60\% of $\mathrm{O}_{2}$ and 4.40-8.10\% of $\mathrm{CO}_{2}$ (Selçuk \& Erkan 2014; 2015), 13.63\% of $\mathrm{O}_{2}$ and $7.85 \%$ of $\mathrm{CO}_{2}(\mathrm{Candir}$ et al. 2018) and $15.30 \%$ of $\mathrm{O}_{2}$ and $7.45 \%$ of $\mathrm{CO}_{2}$ (Candir et al. 2019) for pomegranate fruit for long term storage at $6{ }^{\circ} \mathrm{C}$. $\mathrm{HW}$ treatment did not have any improving effects on the headspace gas concentration inside MAP. 

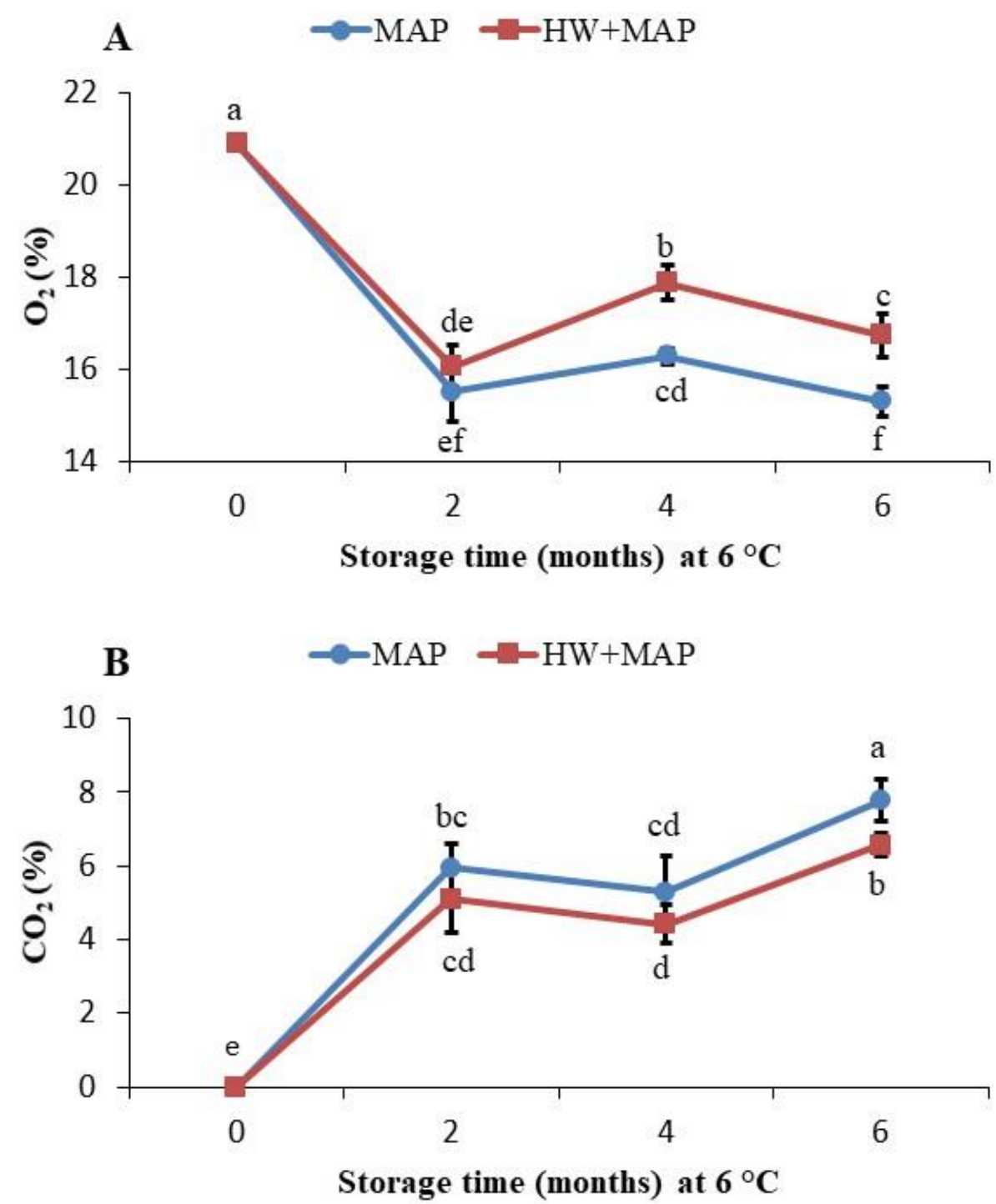

Figure 1- Changes in headspace $\mathrm{O}_{2}(\mathrm{~A})$ and $\mathrm{CO}_{2}(\mathrm{~B})$ concentration (\%) inside the MAP containing hot water treated- or not treated pomegranate fruit cv. Hicaznar during storage at $6^{\circ} \mathrm{C}$. HW: Hot water; MAP: Modified atmosphere packaging

\subsection{Weight loss}

Effects of treatments $\times$ storage period and treatments $\times$ shelf life period interactions on the changes in weight loss were significant $(\mathrm{P}<0.05)$. MAP and $\mathrm{HW}+\mathrm{MAP}$ treatments resulted in a significant reduction in weight loss during cold storage and shelf life period, compared to HW, C and W and treatments (Figure 2). Percent weight loss in MAP and HW+MAP treatments ranged from $9.09 \%$ to $9.64 \%$ after cold storage and from $11.91 \%$ to $12.52 \%$ after shelf life period. HW treatments also lead to reduction in weight loss, but it was not as much as MAP and HW+MAP treatments. The 18.51 and $20.27 \%$ of weight loss occurred in HW treated-fruit after cold storage and shelf life period, respectively. HW dip contributed a slight effect in controlling weight loss in HW+MAP treatment. Percent weight loss were highest in $\mathrm{C}$ and $\mathrm{W}$ treatments and reached to $20.36 \%$ and $22.11 \%$ respectively, after 6 months of storage and exceeded $20 \%$ occurred during shelf life period following cold storage. No shriveling was observed in MAP packaged fruit with or without HW dip. In case of the unpackaged fruit of C, W and HW treatments, the husk became hard and darkened, indicating severe shriveling at the end of cold storage and shelf life period. MAP have been suggested to minimize weight loss of pomegranate fruit during cold storage (Artés et al. 2000b; Nanda et al. 2001; D’Aquino et al. 2010; Selçuk \& Erkan 2014, 2015, 2016; Porat et al. 2016). In agreement with our results, Mirdehghan \& Rahemi (2005) found a lower weight loss occurred in pomegranate fruit from $\mathrm{HW}$ treatment at $50{ }^{\circ} \mathrm{C}$ than control fruit during 3 to 4 months of cold storage. In contrast to our findings, Moradinezhad \& Khayyat (2014) reported that HW treatment alone had no significant effect on weight loss in cold stored pomegranate fruit, compared to control. 

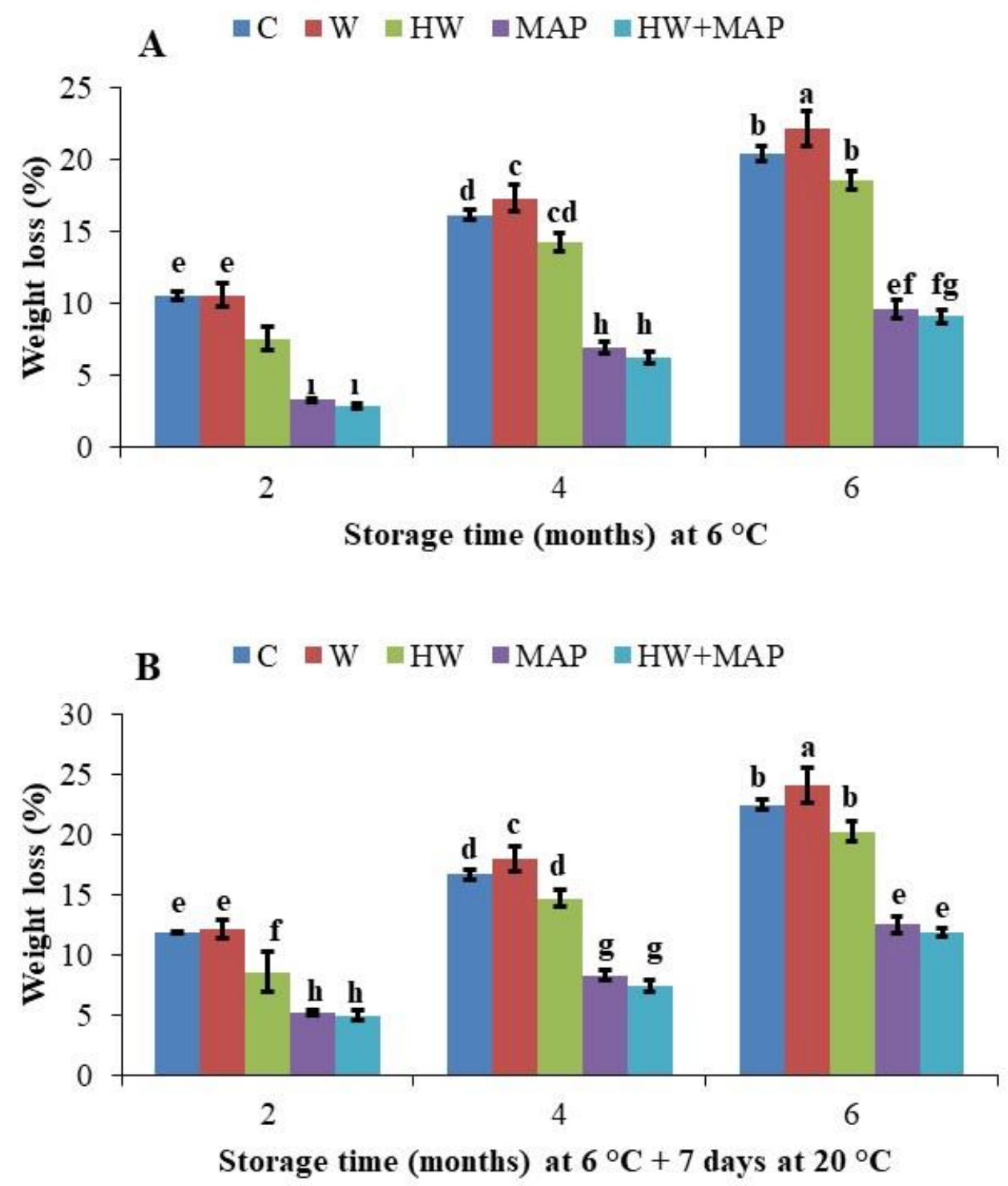

Figure 2- Effects of how water and MAP treatments on the changes in weight loss of Hicaznar pomegranate fruit during storage at $6^{\circ} \mathrm{C}(\mathrm{A})$ and subsequent shelf life period for 7 days at $20^{\circ} \mathrm{C}$ (B). C: Untreated; W: Water; HW: Hot water; MAP: Modified atmosphere packaging

\subsection{SSC and TA}

Treatments $\times$ storage period and treatments $\times$ shelf life period interactions significantly affected on changes in SSC and TA. $(\mathrm{P}<0.05)$. A decrease in SSC and TA occurred in all treatments after cold storage and shelf life period, compared to the values at harvest (Table 1). Pomegranates are non-climacteric fruit and the consumption of acids and sugars by pomegranate fruit via respiration process lead to decrease in SSC and TA during postharvest period (Kader et al. 1984; D'Aquino et al. 2010; Selçuk \& Erkan, 2015, 2016). SSC was similar among the treatments during cold storage period and shelf life period following 2 and 4 months of storage (Table 2). However, control and water treated fruit had higher SSC than the fruit of HW, MAP and HW+MAP treatments after shelf life period following 6 months of storage due to a concentration effect of water loss on sugars (Selçuk \& Erkan 2015). In compared to C treatment, TA was maintained better in HW, MAP and HW+MAP treatments throughout cold storage period, but there is no significant difference in TA among treatments after shelf life period. In pomegranate fruit, TA and SSC were reported not to be affected significantly by HW (Mirdehghan \& Rahemi 2005; Ben Abda et al. 2010; Kipri \& Dündar, 2011; Ramezanian \& Rahemi 2010; Sepahvand et al. 2013; Moradinezhad \& Khayyat 2014), MAP (Artés et al. 2000b; D’Aquino et al. 2010; Selçuk \& Erkan 2015; 2016) or HW+MAP (Moradinezhad et al. 2013) treatments according to the results some studies. In contrast, other studies showed that TA was maintained better in pomegranate fruit dipped in hot water (Mirdehghan et al. 2006) or packaged MAP (Nanda et al. 2001; Selçuk \& Erkan 2014; Candir et al. 2018; 2019) in comparison to control during cold storage and shelf life period. In our study, HW+MAP treatment did not have additive beneficial effect in maintaining SSC and TA, compared to individual application of each treatment. 
Table 1- Effects of how water and MAP treatments on some quality parameters of Hicaznar pomegranate fruit during 6 months of storage at $6^{\circ} \mathrm{C}$

\begin{tabular}{|c|c|c|c|c|c|c|c|c|}
\hline \multirow{2}{*}{ Treatments $^{1}$} & \multirow{2}{*}{$\begin{array}{c}S S C \\
(\%)\end{array}$} & \multirow{2}{*}{$\begin{array}{c}T A \\
(\%)\end{array}$} & \multicolumn{3}{|c|}{ Husk color } & \multicolumn{3}{|c|}{ Aril color } \\
\hline & & & $L^{*}$ & $C^{*}$ & $h^{\circ}$ & $L^{*}$ & $C^{*}$ & $h^{\circ}$ \\
\hline \multirow[t]{2}{*}{ At harvest } & $17.62 a^{2}$ & $1.38 a$ & $43.90 a$ & $49.68 a$ & $25.11 g$ & $32.70 a$ & $24.51 e$ & $29.73 a$ \\
\hline & \multicolumn{8}{|c|}{2 months of cold storage at $6^{\circ} \mathrm{C}$} \\
\hline$\overline{\mathrm{C}}$ & $17.30 \mathrm{abc}$ & $1.20 \mathrm{~cd}$ & $42.32 \mathrm{bc}$ & $44.92 \mathrm{cde}$ & $27.99 \mathrm{bcd}$ & $31.39 \mathrm{a}$ & $27.84 \mathrm{~cd}$ & $27.04 \mathrm{~b}$ \\
\hline W & $16.87 \mathrm{cde}$ & $1.12 \mathrm{ef}$ & $41.46 \mathrm{~cd}$ & $44.29 \mathrm{def}$ & $27.90 \mathrm{bcd}$ & $27.76 \mathrm{a}$ & $26.99 \mathrm{~d}$ & $25.66 \mathrm{bcd}$ \\
\hline HW & $17.40 \mathrm{ab}$ & $1.23 b c$ & $41.64 \mathrm{~cd}$ & $44.97 \mathrm{~cd}$ & $25.60 \mathrm{fg}$ & $31.60 \mathrm{a}$ & $27.89 \mathrm{~cd}$ & $27.02 \mathrm{~b}$ \\
\hline MAP & $17.33 \mathrm{ab}$ & $1.24 b c$ & $43.79 \mathrm{a}$ & $49.38 \mathrm{a}$ & $25.65 \mathrm{fg}$ & $32.62 \mathrm{a}$ & $26.70 \mathrm{~d}$ & $26.13 b c$ \\
\hline \multirow[t]{2}{*}{ HW+MAP } & $17.23 \mathrm{abc}$ & $1.25 \mathrm{~b}$ & $43.79 \mathrm{a}$ & $49.71 \mathrm{a}$ & $25.82 \mathrm{fg}$ & $31.53 \mathrm{a}$ & $26.62 \mathrm{~d}$ & $26.23 b c$ \\
\hline & \multicolumn{8}{|c|}{4 months of cold storage at $6^{\circ} \mathrm{C}$} \\
\hline$\overline{\mathrm{C}}$ & 17.23abc & $1.06 \mathrm{~g}$ & $40.61 \mathrm{~d}$ & 43.03fgh & $28.87 \mathrm{~b}$ & $28.28 \mathrm{~cd}$ & $30.35 a$ & $25.22 \mathrm{cde}$ \\
\hline W & 16.70def & $0.98 \mathrm{~h}$ & $40.57 \mathrm{~d}$ & $43.17 \mathrm{fg}$ & $28.77 \mathrm{~b}$ & $24.81 \mathrm{e}$ & $27.78 \mathrm{~cd}$ & $26.08 \mathrm{bcd}$ \\
\hline HW & $17.23 \mathrm{abc}$ & $1.16 \mathrm{de}$ & $41.19 \mathrm{~cd}$ & 43.0efg & $27.35 \mathrm{cde}$ & $29.05 \mathrm{~cd}$ & $28.62 b c$ & $26.34 b c$ \\
\hline MAP & $17.07 \mathrm{bcd}$ & $1.13 \mathrm{e}$ & $43.07 \mathrm{ab}$ & $46.74 \mathrm{~b}$ & $26.22 \mathrm{efg}$ & $32.75 \mathrm{a}$ & $28.34 \mathrm{bc}$ & $26.27 b c$ \\
\hline \multirow[t]{2}{*}{$\underline{\mathrm{HW}+\mathrm{MAP}}$} & $17.07 \mathrm{bcd}$ & $1.16 \mathrm{de}$ & $43.22 \mathrm{ab}$ & $46.14 \mathrm{bc}$ & $27.22 \mathrm{de}$ & $31.15 \mathrm{ab}$ & $28.73 \mathrm{bc}$ & $25.72 \mathrm{bcd}$ \\
\hline & \multicolumn{8}{|c|}{6 months of cold storage at $6^{\circ} \mathrm{C}$} \\
\hline$\overline{\mathrm{C}}$ & $16.57 \mathrm{ef}$ & $1.01 \mathrm{~h}$ & $40.80 \mathrm{~d}$ & 42.22gh1 & $31.20 \mathrm{a}$ & $25.57 \mathrm{c}$ & $30.69 \mathrm{a}$ & $24.55 \mathrm{de}$ \\
\hline $\mathrm{W}$ & $16.73 \mathrm{def}$ & $1.00 \mathrm{~h}$ & $40.78 \mathrm{~d}$ & 41.161 & $30.93 \mathrm{a}$ & $20.33 \mathrm{de}$ & $29.41 \mathrm{ab}$ & $24.12 \mathrm{e}$ \\
\hline HW & $16.50 \mathrm{ef}$ & $1.07 \mathrm{~g}$ & $41.31 \mathrm{~cd}$ & 41.48h1 & $30.84 \mathrm{a}$ & $25.10 \mathrm{c}$ & $27.56 \mathrm{~cd}$ & $24.87 \mathrm{cde}$ \\
\hline MAP & $16.33 \mathrm{f}$ & $1.08 \mathrm{fg}$ & $43.74 \mathrm{a}$ & $47.40 \mathrm{~b}$ & $26.49 \mathrm{ef}$ & $29.71 b$ & $26.84 d$ & $25.08 \mathrm{cde}$ \\
\hline $\mathrm{HW}+\mathrm{MAP}$ & $16.67 \mathrm{def}$ & $1.06 \mathrm{~g}$ & $42.99 \mathrm{ab}$ & $45.05 \mathrm{~cd}$ & $28.59 \mathrm{bc}$ & $28.00 \mathrm{~b}$ & $27.40 \mathrm{~cd}$ & $25.43 \mathrm{cde}$ \\
\hline
\end{tabular}

${ }^{1} \mathrm{C}$ : Untreated; W: Water; HW: Hot water; MAP: Modified atmosphere packaging, ${ }^{2}$ Means (n=3) followed by different letters within a column are significantly different according to Fisher's LSD test at $\mathrm{P}<0.05$

Table 2-Effects of how water and MAP treatments on some quality parameters of Hicaznar pomegranate fruit after shelf life period for 7 days at $20^{\circ} \mathrm{C}$ following 2,4 and 6 months of storage at $6^{\circ} \mathrm{C}$

\begin{tabular}{|c|c|c|c|c|c|c|c|c|}
\hline \multirow[t]{2}{*}{ Treatments $^{l}$} & \multirow{2}{*}{$\begin{array}{l}S S C \\
(\%)\end{array}$} & \multirow{2}{*}{$\begin{array}{c}T A \\
(\%)\end{array}$} & \multicolumn{3}{|c|}{ Husk color } & \multicolumn{3}{|c|}{ Aril color } \\
\hline & & & $L^{*}$ & $C^{*}$ & $h^{\circ}$ & $L^{*}$ & $C^{*}$ & $h^{\circ}$ \\
\hline At harvest & $17.62 a^{2}$ & $1.38 a$ & $43.90 a b$ & $49.68 a$ & $25.11 c$ & $32.70 a$ & $24.51 d$ & $29.73 d$ \\
\hline \multicolumn{9}{|c|}{ Shelf life for 7 days at $20^{\circ} \mathrm{C}$ after 2 months of cold storage } \\
\hline$\overline{\mathrm{C}}$ & $17.27 \mathrm{abc}$ & $1.20 \mathrm{~cd}$ & $43.17 \mathrm{bcd}$ & $44.83 \mathrm{~cd}$ & $25.69 \mathrm{c}$ & $25.58 \mathrm{ef}$ & $27.05 b c$ & $30.83 c$ \\
\hline W & $17.10 \mathrm{c}$ & $1.23 \mathrm{~cd}$ & $43.13 \mathrm{bcd}$ & $44.98 \mathrm{~cd}$ & $25.64 \mathrm{c}$ & $21.27 \mathrm{~g}$ & $27.17 b c$ & $31.05 \mathrm{bc}$ \\
\hline HW & $17.20 b c$ & $1.24 \mathrm{c}$ & $43.75 \mathrm{ab}$ & $45.44 \mathrm{bc}$ & $25.59 \mathrm{c}$ & $26.65 \mathrm{~d}$ & $26.20 \mathrm{c}$ & $29.47 \mathrm{de}$ \\
\hline MAP & $17.17 b c$ & $1.31 \mathrm{~b}$ & $44.11 \mathrm{a}$ & $46.87 \mathrm{~b}$ & $23.82 \mathrm{c}$ & $30.51 b$ & $27.68 b c$ & $29.46 \mathrm{de}$ \\
\hline HW+MAP & $17.17 b c$ & $1.25 b c$ & $43.83 \mathrm{ab}$ & $45.85 b c$ & $24.55 c$ & $28.81 \mathrm{c}$ & $26.98 b c$ & $29.06 \mathrm{def}$ \\
\hline \multicolumn{9}{|c|}{ Shelf life for 7 days at $20^{\circ} \mathrm{C}$ after 4 months of cold storage } \\
\hline $\mathrm{C}$ & $17.35 \mathrm{abc}$ & $1.01 \mathrm{f}$ & $42.58 \mathrm{de}$ & $41.52 \mathrm{fg}$ & $29.06 \mathrm{~b}$ & 25.96de & $31.24 \mathrm{a}$ & $31.27 b c$ \\
\hline W & $17.10 \mathrm{c}$ & $1.06 \mathrm{f}$ & $42.73 \mathrm{cde}$ & 41.44fg & $29.02 b$ & $21.78 \mathrm{~g}$ & $30.84 a$ & $31.93 \mathrm{ab}$ \\
\hline HW & $17.23 b c$ & $1.13 \mathrm{e}$ & $43.43 \mathrm{abc}$ & 42.46ef & $24.26 \mathrm{c}$ & $26.43 \mathrm{de}$ & $27.13 b c$ & 28.70efg \\
\hline MAP & $17.20 \mathrm{bc}$ & $1.25 b c$ & $43.70 \mathrm{ab}$ & $45.14 \mathrm{~cd}$ & $25.41 \mathrm{c}$ & $30.24 b$ & $26.59 b c$ & $28.09 \mathrm{~g}$ \\
\hline $\mathrm{HW}+\mathrm{MAP}$ & $17.13 \mathrm{c}$ & $1.17 \mathrm{de}$ & $43.88 \mathrm{ab}$ & $45.42 \mathrm{bc}$ & $25.44 \mathrm{c}$ & $28.33 \mathrm{c}$ & $27.75 b c$ & $29.07 \mathrm{def}$ \\
\hline \multicolumn{9}{|c|}{ Shelf life for 7 days at $20^{\circ} \mathrm{C}$ after 6 months of cold storage } \\
\hline$\overline{\mathrm{C}}$ & $17.00 \mathrm{c}$ & $1.02 \mathrm{f}$ & $38.89 \mathrm{f}$ & $39.74 \mathrm{~h}$ & $32.03 \mathrm{a}$ & $22.14 \mathrm{~g}$ & $30.24 \mathrm{a}$ & $32.47 \mathrm{a}$ \\
\hline W & $17.53 \mathrm{ab}$ & $1.02 \mathrm{f}$ & $38.97 f$ & $39.87 \mathrm{~h}$ & $32.41 \mathrm{a}$ & $20.08 \mathrm{~h}$ & $30.48 \mathrm{a}$ & $31.91 \mathrm{ab}$ \\
\hline HW & $15.53 \mathrm{~d}$ & $1.03 \mathrm{f}$ & $39.66 \mathrm{f}$ & $40.53 \mathrm{gh}$ & $31.38 \mathrm{a}$ & $24.90 \mathrm{f}$ & $28.01 \mathrm{~b}$ & $29.79 d$ \\
\hline MAP & $14.98 \mathrm{e}$ & $1.03 \mathrm{f}$ & $42.67 \mathrm{cde}$ & 43.81de & $27.78 b$ & $28.67 \mathrm{c}$ & $26.67 b c$ & $28.15 \mathrm{fg}$ \\
\hline $\mathrm{HW}+\mathrm{MAP}$ & $15.27 \mathrm{de}$ & $1.01 \mathrm{f}$ & $41.96 \mathrm{e}$ & $43.84 \mathrm{de}$ & $29.33 b$ & $28.82 \mathrm{c}$ & $27.62 b c$ & $29.29 \mathrm{de}$ \\
\hline
\end{tabular}

${ }^{1}$ C: Untreated; W: Water; HW: Hot water; MAP: Modified atmosphere packaging, ${ }^{2}$ Means ( $\mathrm{n}=3$ ) followed by different letters within a column are significantly different according to Fisher's LSD test at $\mathrm{P}<0.05$

\subsection{Husk and aril color}

Husk and aril color were significantly affected by treatments $\times$ storage period and treatments $\times$ shelf life period interactions $(\mathrm{P}<0.05)$. Husk color $\mathrm{L}^{*}$ (lightness) and $\mathrm{C}^{*}$ (intensity) values were lower while $\mathrm{h}^{\circ}$ values were higher after 6 months of cold storage and shelf life period, compared to the initial values (Table 1 and 2). Similar changes in husk color of cold stored pomegranate fruit have been previously reported (Fawole \& Opara 2013; Selçuk \& Erkan 2013; 2014; 2015; 2016; Candir et al. 2018; 2019). A significantly higher water loss resulted in loss of husk color lightness (lower $\mathrm{L}^{*}$ values) in the unpackaged fruit from $\mathrm{C}, \mathrm{W}$ and $\mathrm{HW}$ treatments. In comparison to the unpackaged fruit $(\mathrm{C}, \mathrm{W}$ and $\mathrm{HW}$ treatments), the lightness and red color intensity of husk (higher values of $\mathrm{L}^{*}$ and $\mathrm{C}^{*}$ and lower values of $\mathrm{h}^{\circ}$ ) were maintained better in the packaged fruit with MAP (MAP + HW+MAP treatments) as reported in previous studies (Artés et al. 2000b; D'Aquino et al. 2010; Selçuk \& Erkan 2013; 2014; 2015; 2016; Candir et al. 2018; 2019). Stand-alone MAP treatment was found to be effective in maintaining 
husk color. HW treatment was not successful in preventing husk color loss as $\mathrm{C}$ and $\mathrm{W}$ treatments. Therefore, we concluded that there is no improvement in husk color due to HW or HW+MAP treatments. Consistent with our findings, Kipri \& Dündar (2011) reported no significant effect of $\mathrm{HW}$ treatments at $50{ }^{\circ} \mathrm{C}$ to $55{ }^{\circ} \mathrm{C}$ for $1-2$ min on husk color. Sepahvand et al. (2013) found no significant differences in husk color $\mathrm{a}^{*}$ and $\mathrm{b}^{*}$ values between $\mathrm{HW}$-treated and control pomegranate fruit $\mathrm{cv}$. 'Malas Saveh', but HW treatments resulted in lower husk color L* values than control treatment after storage and shelf life period.

Aril color $\mathrm{L}^{*}$ and $\mathrm{h}^{\circ}$ values decreased and aril color intensity $\left(\mathrm{C}^{*}\right)$ increased after 6 months of storage, compared to values at harvest (Table 1), indicating resulting in more intense aril color. Arendse et al. (2014) found similar changes in aril color $\mathrm{L}^{*}$, $\mathrm{C}^{*}$ and $\mathrm{h}^{\circ}$ values of pomegranate fruit cv. 'Wonderful' kept at $5{ }^{\circ} \mathrm{C}$ for 5 months. They reported that anthocyanin synthesis and accumulation is continued in the cold stored pomegranate fruit. Fruit from $\mathrm{C}$ and $\mathrm{W}$ treatments had darker (lower $\left.\mathrm{L}^{*}\right)$ and more intense (higher $\mathrm{C}^{*}$ ) aril color than those from HW, MAP and HW+MAP treatments after cold storage and shelf life period. Aril color $\mathrm{h}^{\circ}$ values were similar among the treatments after 6 months of cold storage. However, $\mathrm{C}$ and $\mathrm{W}$ treatments resulted in higher $\mathrm{h}^{\circ}$ values than HW, MAP and HW+MAP treatments during shelf life period following 6 months of cold storage (Table 2). This indicates discoloration of aril color in $\mathrm{C}$ and $\mathrm{W}$ treatments. Previous studies reported that aril color was not affected by HW treatment (Ben Abda 2010; Kipri \& Dündar 2011). However, we found that stand-alone HW treatment and combination with MAP treatment was successful in maintaining aril color as MAP treatment did. Candir et al. (2019) reported a delay of discoloration of aril color in pomegranate fruit packaged with MAP compared to unpackaged control fruit during prolonged cold storage.

\subsection{Husk scald, fungal decay, visual quality and taste}

Husk scald, fungal decay visual quality and taste were significantly affected by treatments $\times$ storage period and treatments $\times$ shelf life period interactions $(\mathrm{P}<0.05)$. Husk scald symptoms and fungal decay were not observed until 6 months of storage and subsequent shelf life period, except for control treatment (Table 3 and 4). After 4 months of storage plus 7 days at $20{ }^{\circ} \mathrm{C}$, scald incidence of $17.78 \%$ was observed only on control fruits. Incidence of husk scald was lower in MAP and HW+MAP treatments than HW, C and W after 6 months of cold storage and shelf life period. Severity of scald was low since only <10\% of the skin's surface area covered with and scald symptoms. Fungal decay incidence was significantly reduced by HW, MAP and HW+MAP treatments compared to $\mathrm{C}$ and Win both cold storage and shelf life period. How water dip at $50^{\circ} \mathrm{C}$ for 3 min was found previously effective in reducing chilling injury of pomegranate fruit packaged with low-density polyethylene bags during 10 weeks of cold storage (Moradinezhad \& Khayyat 2014). In our study, chilling injury symptoms were not observed in any of treatments. We found that stand-alone HW treatment was not effective as MAP and HW+MAP treatments in controlling husk scald. There is no improvement in preventing husk scald when combined HW treatment with MAP treatment. Ben-Arie \& Or (1986) suggested that oxidation of phenolic compounds on the husk of pomegranates may resulted in husk scald when stored at $>5{ }^{\circ} \mathrm{C}$. Lower scald incidence was reported in 'Wonderful', 'Primosole' and 'Hicaznar' pomegranates stored in MAP bags for 12 to 16 weeks in comparison to unpackaged control fruit (D’Aquino et al. 2010; Porat et al. 2016; Candir et al. 2019). According to D'Aquino et al. (2010), lower O2 levels in MAP bags may reduce or delay oxidation of phenolic compounds on the husk and consequently could control scald incidence in pomegranate fruits packaged with MAP bags.

Table 3- Effects of how water and MAP treatments on the incidence of husk scald and fungal decay and visual quality and taste of Hicaznar pomegranate fruit after 6 months of storage at $6^{\circ} \mathrm{C}$

\begin{tabular}{|c|c|c|c|c|c|}
\hline Treatments $^{l}$ & Husk scald $(\%)$ & Severity of scald ${ }^{3}$ & Fungal decay (\%) & Visual quality $^{4}$ & Taste $^{5}$ \\
\hline At harvest & $0.00 d^{2}$ & $1.00 \mathrm{~b}$ & $0.00 c$ & $5.00 a$ & $9.00 a$ \\
\hline \multicolumn{6}{|c|}{2 months of cold storage at $6^{\circ} \mathrm{C}$} \\
\hline $\mathrm{C}$ & $0.00 \mathrm{~d}$ & $1.00 \mathrm{~b}$ & $0.00 \mathrm{c}$ & $4.87 \mathrm{a}$ & $7.00 \mathrm{cde}$ \\
\hline $\mathrm{W}$ & $0.00 \mathrm{~d}$ & $1.00 \mathrm{~b}$ & $0.00 \mathrm{c}$ & $5.00 \mathrm{a}$ & $7.17 \mathrm{~cd}$ \\
\hline HW & $0.00 \mathrm{~d}$ & $1.00 \mathrm{~b}$ & $0.00 \mathrm{c}$ & $4.93 \mathrm{a}$ & $7.67 \mathrm{bc}$ \\
\hline MAP & $0.00 \mathrm{~d}$ & $1.00 \mathrm{~b}$ & $0.00 \mathrm{c}$ & $5.00 \mathrm{a}$ & $8.50 \mathrm{ab}$ \\
\hline HW+MAP & $0.00 \mathrm{~d}$ & $1.00 \mathrm{~b}$ & $0.00 \mathrm{c}$ & $5.00 \mathrm{a}$ & $7.08 \mathrm{cde}$ \\
\hline \multicolumn{6}{|c|}{4 months of cold storage at $6^{\circ} \mathrm{C}$} \\
\hline $\mathrm{C}$ & $0.00 \mathrm{~d}$ & $1.00 \mathrm{~b}$ & $0.00 \mathrm{c}$ & $2.20 \mathrm{e}$ & $6.17 \mathrm{e}$ \\
\hline W & $0.00 \mathrm{~d}$ & $1.00 \mathrm{~b}$ & $0.00 \mathrm{c}$ & $2.73 \mathrm{~d}$ & $6.17 \mathrm{e}$ \\
\hline HW & $0.00 \mathrm{~d}$ & $1.00 \mathrm{~b}$ & $0.00 \mathrm{c}$ & $1.53 \mathrm{f}$ & $6.50 \mathrm{de}$ \\
\hline MAP & $0.00 \mathrm{~d}$ & $1.00 \mathrm{~b}$ & $0.00 \mathrm{c}$ & $4.77 \mathrm{a}$ & $7.00 \mathrm{cde}$ \\
\hline HW+MAP & $0.00 \mathrm{~d}$ & $1.00 \mathrm{~b}$ & $0.00 \mathrm{c}$ & $4.73 \mathrm{a}$ & $7.00 \mathrm{cde}$ \\
\hline \multicolumn{6}{|c|}{6 months of cold storage at $6^{\circ} \mathrm{C}$} \\
\hline $\mathrm{C}$ & $41.48 \mathrm{a}$ & $2.12 \mathrm{a}$ & $37.78 \mathrm{a}$ & $1.00 \mathrm{~g}$ & $6.42 \mathrm{de}$ \\
\hline $\mathrm{W}$ & $37.78 \mathrm{a}$ & $2.11 \mathrm{a}$ & $41.48 \mathrm{a}$ & $1.00 \mathrm{~g}$ & $6.44 \mathrm{de}$ \\
\hline HW & $23.71 b$ & $2.12 \mathrm{a}$ & $0.00 \mathrm{c}$ & $1.00 \mathrm{~g}$ & 6.39de \\
\hline MAP & $13.34 \mathrm{c}$ & $2.14 \mathrm{a}$ & $0.00 \mathrm{c}$ & $3.59 \mathrm{~b}$ & $6.89 \mathrm{cde}$ \\
\hline HW+MAP & $12.2 \mathrm{c}$ & $2.15 \mathrm{a}$ & $7.78 \mathrm{~b}$ & $3.15 \mathrm{c}$ & $6.72 \mathrm{de}$ \\
\hline
\end{tabular}

${ }^{1} \mathrm{C}$ : Untreated; W: Water; HW: Hot water; MAP: Modified atmosphere packaging, ${ }^{2}$ Means $(\mathrm{n}=3)$ followed by different letters within a column are significantly different according to Fisher's LSD test at $\mathrm{P}<0.05,{ }^{3}$ Assessed based on a $1-6$ scale, $(1=$ no scald; $2=<10 \% ; 3=11-25 \% ; 4=25-50 \% ; 5=50-75 \% ; 6=\% 75-100$ of the fruit surface affected), ${ }^{4}$ Evaluated based on a 5 point scale, where: $1=$ very poor; $2=$ poor (limit of marketability); $3=$ good; $4=$ very good; $5=$ excellent. ${ }^{5}$ Evaluated based on a hedonic scale of $1=$ disliked extremely to $9=$ liked extremely 
Table 4- Effects of how water and MAP treatments on the incidence of husk scald and fungal decay and visual quality and taste of Hicaznar pomegranate fruit after shelf life period for 7 days at $20{ }^{\circ} \mathrm{C}$ following 2,4 and 6 months of storage at $6^{\circ} \mathrm{C}$

\begin{tabular}{|c|c|c|c|c|c|}
\hline Treatments $^{l}$ & Husk scald $(\%)$ & Severity of scald ${ }^{3}$ & Fungal decay $(\%)$ & Visual quality $^{4}$ & Taste $^{5}$ \\
\hline$A T$ & $0.00 d$ & $1.00 \mathrm{~b}$ & $0.00 b$ & $5.00 a$ & $9.00 a$ \\
\hline \multicolumn{6}{|c|}{ Shelf life for 7 days at $20^{\circ} \mathrm{C}$ after 2 months of cold storage } \\
\hline $\mathrm{C}$ & $0.00 \mathrm{~d}$ & $1.00 \mathrm{~b}$ & $0.00 \mathrm{~b}$ & $4.87 \mathrm{ab}$ & $8.17 \mathrm{~b}$ \\
\hline $\mathrm{W}$ & $0.00 \mathrm{~d}$ & $1.00 \mathrm{~b}$ & $0.00 \mathrm{~b}$ & $4.73 \mathrm{ab}$ & $6.20 \mathrm{de}$ \\
\hline HW & $0.00 \mathrm{~d}$ & $1.00 \mathrm{~b}$ & $0.00 \mathrm{~b}$ & $4.87 \mathrm{ab}$ & $7.50 \mathrm{c}$ \\
\hline MAP & $0.00 \mathrm{~d}$ & $1.00 \mathrm{~b}$ & $0.00 \mathrm{~b}$ & $5.00 \mathrm{a}$ & $6.00 \mathrm{ef}$ \\
\hline $\mathrm{HW}+\mathrm{MAP}$ & $0.00 \mathrm{~d}$ & $1.00 \mathrm{~b}$ & $0.00 \mathrm{~b}$ & $4.93 \mathrm{ab}$ & $6.33 \mathrm{de}$ \\
\hline \multicolumn{6}{|c|}{ Shelf life for 7 days at $20^{\circ} \mathrm{C}$ after 4 months of cold storage } \\
\hline $\mathrm{C}$ & $17.78 \mathrm{c}$ & $2.27 \mathrm{a}$ & $0.00 \mathrm{~b}$ & $4.27 \mathrm{c}$ & $6.38 \mathrm{de}$ \\
\hline $\mathrm{W}$ & $0.00 \mathrm{~d}$ & $1.00 \mathrm{~b}$ & $0.00 \mathrm{~b}$ & $2.48 \mathrm{f}$ & $6.61 \mathrm{~d}$ \\
\hline HW & $0.00 \mathrm{~d}$ & $1.00 \mathrm{~b}$ & $0.00 \mathrm{~b}$ & $2.85 \mathrm{ef}$ & $5.89 \mathrm{ef}$ \\
\hline MAP & $0.00 \mathrm{~d}$ & $1.00 \mathrm{~b}$ & $0.00 \mathrm{~b}$ & $4.57 \mathrm{bc}$ & $7.38 \mathrm{c}$ \\
\hline $\mathrm{HW}+\mathrm{MAP}$ & $0.00 \mathrm{~d}$ & $1.00 \mathrm{~b}$ & $0.00 \mathrm{~b}$ & $3.53 \mathrm{~d}$ & $7.22 \mathrm{c}$ \\
\hline \multicolumn{6}{|c|}{ Shelf life for 7 days at $20^{\circ} \mathrm{C}$ after 6 months of cold storage } \\
\hline $\mathrm{C}$ & $40.00 \mathrm{a}^{2}$ & $2.43 \mathrm{a}$ & $36.67 \mathrm{a}$ & $1.00 \mathrm{~g}$ & $5.28 \mathrm{~g}$ \\
\hline $\mathrm{W}$ & $37.50 \mathrm{a}$ & $2.38 \mathrm{a}$ & $40.00 \mathrm{a}$ & $1.00 \mathrm{~g}$ & $4.45 \mathrm{~h}_{1}$ \\
\hline HW & $36.67 \mathrm{a}$ & $2.37 \mathrm{a}$ & $0.00 \mathrm{~b}$ & $1.00 \mathrm{~g}$ & 4.061 \\
\hline MAP & $27.41 \mathrm{~b}$ & $2.23 \mathrm{bc}$ & $2.22 b$ & $3.20 \mathrm{de}$ & $5.44 \mathrm{fg}$ \\
\hline $\mathrm{HW}+\mathrm{MAP}$ & $28.34 \mathrm{~b}$ & $2.33 \mathrm{ab}$ & $0.00 \mathrm{~b}$ & $2.93 \mathrm{e}$ & $4.97 \mathrm{gh}$ \\
\hline
\end{tabular}

${ }^{1}$ C: Untreated; W: Water; HW: Hot water; MAP: Modified atmosphere packaging, ${ }^{2}$ Means $(\mathrm{n}=3)$ followed by different letters within a column are significantly different according to Fisher's LSD test at $\mathrm{P}<0.05,{ }^{3}$ Assessed based on a $1-6$ scale, $(1=$ no scald; $2=<10 \% ; 3=11-25 \% ; 4=25-50 \% ; 5=50-75 \%$; $6=\% 75-100$ of the fruit surface affected), ${ }^{4}$ Evaluated based on a 5 point scale, where: $1=$ very poor; $2=$ poor (limit of marketability); $3=$ good; $4=$ very good; $5=$ excellent, ${ }^{5}$ Evaluated based on a hedonic scale of $1=$ disliked extremely to $9=$ liked extremely

HW and HW+MAP treatment was more effective in reducing decay, compared to MAP treatment. Effectiveness of HW treatment and its combination with MAP treatment in controlling fungal decay of pomegranate fruit was previously reported (Ben Abda et al. 2010; Kipri \& Dündar 2011; Moradinezhad et al. 2013; Moradinezhad \& Khayyat 2014). MAP treatment did not affect decay incidence in pomegranate fruits cv. Mollar de Elche (Artés et al. 2000b) and Wonderful (Porat et al. 2016) during cold storage and shelf life period. In contrast, Candir et al. (2019) observed lower decay percentage in 'Hicaznar' pomegranates packaged with MAP bags than control.

The unpackaged fruit from $\mathrm{HW}, \mathrm{C}$ and $\mathrm{W}$ treatments became unmarketable while those from MAP and HW+MAP treatments were still marketable after 6 months of cold storage and 7 days at $20^{\circ} \mathrm{C}$. Higher incidence of fungal decay, weight loss and husk scald impaired visual quality in the fruit of $\mathrm{C}$ and $\mathrm{W}$ treatments. Although fungal decay incidence was low in HW-treated fruit, relatively high scald incidence and weight loss had adverse effect on overall visual acceptability of HWtreated fruit. Taste of fruits received lower scores as storage time extended in all treatments. The taste of fruits was rated as acceptable (>5) after 6 months cold storage plus shelf life period except for $\mathrm{W}$ and HW treatments. MAP, HW+MAP and control treatments received higher taste score than W and HW treatments after shelf life period following 6 months of cold storage.

\section{Conclusions}

MAP and HW+MAP treatments was effective in reducing weight loss, husk scald and fungal decay, and maintaining husk and aril color and overall visual quality at $6 \pm 0.5{ }^{\circ} \mathrm{C}$ and $90 \pm 5 \%$ relative humidity for 6 months of cold storage and the subsequent shelf life period at $20 \pm 1{ }^{\circ} \mathrm{C}$ and $70 \pm 5 \%$ relative humidity for 7 days. Although $\mathrm{HW}$ treatment reduced weight loss and fungal decay, was not effective as MAP and HW+MAP treatments to maintain quality parameters.

\section{Acknowlegments}

We wish to thank Meriç Özkan from Aypek Ambalaj Ltd. Co., (Bursa, Turkey) supplying Life Pack® MAP bags. 


\section{References}

Arendse E, Fawole O A \& Opara U L (2014). Influence of storage temperature and duration on postharvest physico-chemical and mechanical properties of pomegranate fruit and arils. CyTA-Journal of Food 12(4): 389-398 10.1080/19476337.2014.900114

Artés F, Tudela J A \&, Gil M I (1998). Improving the keeping quality of pomegranate fruit by intermittent warming. European Food Research and Technology 207: 316-321 10.1007/s002170050339

Artés F, Tudela J A \& Villaescusa R (2000a). Thermal postharvest treatments for improving pomegranate quality and shelf life. Postharvest Biology and Technology 18: 245-251 10.1016/S0925-5214(00)00066-1

Artés F, Villaescusa R \& Tudela J A (2000b). Modified atmosphere packaging of pomegranate. Journal of Food Science 65: 1112-1116 $10.1111 / j .1365-2621.2000 . t b 10248 . x$

Ben-Arie R \& Or E (1986). The development and control of husk scald on 'Wonderful' pomegranate fruit during storage. Journal of the American Society for Horticultural Science 111: 395-399

Ben Abda J, Yahyaoui N, Mars M, Sdiri S \& Salvador-Pèrez A (2010). Effect of intermittent warming, hot water treatment and heat conditioning on quality of 'Jbali' stored pomegranate. Acta Horticulturae 877:1433-1439 10.17660/ActaHortic.2010.877.196

Candir E, Ozdemir A E \& Aksoy M C (2018). Effects of chitosan coating and modified atmosphere packaging on postharvest quality and bioactive compounds of pomegranate fruit cv. 'Hicaznar'. Scientia Horticulturae 235: 235-243 10.1016/j.scienta.2018.03.017

Candir E, Ozdemir A E \& Aksoy M C (2019). Effects of modified atmosphere packaging on the storage and shelf life of 'Hicaznar' pomegranate fruits. Turkish Journal of Agriculture and Forestry 43: 241-253 10.3906/tar-1801-119

D'Aquino S, Palma A, Schirra M, Continella A, Tribulato E \& La Malfa S (2010). Influence of film wrapping and fludioxonil application on quality of pomegranate fruit. Postharvest Biology and Technology 55: 121-128 10.1016/j.postharvbio.2009.08.006

Defilippi B G, Whitaker B D, Hess-Pierce B M \& Kader A A (2006). Development and control of scald on Wonderful pomegranates during long-term storage. Postharvest Biology and Technology 41: 234-243 10.1016/j.postharvbio.2006.04.006

Fawole O A \& Opara U L (2013). Effects of storage temperature and duration on physiological responses of pomegranate fruit. Industrial Crops and Products 47: 300-309 10.1016/j.indcrop.2013.03.028

Kader A A, Chordas A \& Elyatem S (1984). Response of pomegranates to ethylene treatment and storage temperature. California Agriculture 38: 14-15

Kipri N \& Dündar Ö (2011). Effect of postharvest hot water application on pomegranate storage quality (cv. Hicaznar) (In Turkish). Çukurova Üniversitesi Fen ve Mühendislik Bilimleri Dergisi 26(3): 195-204

Mirdehghan S H \& Rahemi M (2005). Effects of hot water treatment on reducing chilling injury of pomegranate (Punica granatum) fruit during storage. Acta Horticulturae 682: 887-892 10.17660/ActaHortic.2005.682.115

Mirdehghan S H, Rahemi M, Serrano M, Guillen F, Martinez-Romero D \& Valero D (2006). Prestorage heat treatment to maintain nutritive and functional properties during postharvest cold storage of pomegranate. Journal of Agricultural and Food Chemistry 54: 8495-8500 $10.1021 /$ jf0615146

Mirdehghan S H, Rahemi D, Martinez-Romero D, Guillen F, Valverde J M, Zapata P J, Serrano M \& Valero D (2007). Reduction of pomegranate chilling injury during storage after heat treatment: Role of polyamines. Postharvest Biology and Technology 44: 19-25 10.1016/j.postharvbio.2006.11.001

Moradinezhad F, Khayyat M \& Saeb H (2013). Combination effects of postharvest treatments and modified atmosphere packaging on shelf life and quality of Iranian pomegranate fruit cv. Sheshi-kab. International Journal of Postharvest Technology and Innovation 3:244-256. 10.1504/IJPTI.2013.059286

Moradinezhad F \& Khayyat M (2014). Effects of intermittent warming and prestorage treatments (Hot water, salicylic acid, Calcium Chloride) on postharvest life of pomegranate fruit cv. 'Shishe-Kab' during long-term cold storage. International Journal of Horticultural Science and Technology 1: 43-51 10.22059/IJHST.2014.50517

Nanda S, Sudhakar Rao D V \& Krishnamurthy S (2001). Effects of shrink film wrapping and storage temperature on the shelf life and quality of pomegranate fruits cv. Ganesh. Postharvest Biology and Technology 22: 61-69 10.1016/S0925-5214(00)00181-2

Porat R, Kosto I \& Daus A (2016). Bulk storage of "Wonderful" pomegranate fruit using modified atmosphere bags. Israel Journal of Plant Sciences 63: 45-50 10.1080/07929978.2016.1152839

Ramezanian A \& Rahemi M (2010). Effects of pre-storage application of spermidine, calcium chloride and hot water on chilling injury of cold stored pomegranates. Acta Horticulturae 877: 491-498 10.17660/ActaHortic.2010.877.63

Rymon D (2012). The prices in Europe of pomegranates and arils. Retrieved in January 2, 2017 from http://om.ciheam.org/om/pdf/a103/00006901.pdf

SAS (2019). SAS Users Guide SAS/STAT Version 9.4. SAS Institute Inc., Cary, N.C.

Selçuk N \& Erkan M (2013). The effects of modified atmosphere packaging on the antioxidant activity and postharvest physiology of 'Canernar-1' pomegranates. Akdeniz Üniversitesi Ziraat Fakültesi Dergisi 26: 81-87 (In Turkish)

Selçuk N \& Erkan M (2014). Changes in antioxidant activity and postharvest quality of sweet pomegranates cv. Hicrannar under modified atmosphere packaging. Postharvest Biology and Technology 92: 29-36 10.1016/j.postharvbio.2014.01.007

Selçuk N \& Erkan M (2015). Changes in phenolic compounds and antioxidant activity of sour-sweet pomegranates cv. 'Hicaznar' during long-term storage under modified atmosphere packaging. Postharvest Biology and Technology 109: 30-39 10.1016/j.postharvbio.2015.05.018

Selçuk N \& Erkan M (2016). Impact of passive modified atmosphere packaging on physicochemical properties, bioactive compounds, and quality attributes of sweet pomegranates. Turkish Journal of Agriculture and Forestry 40: 475-488 10.3906/tar-1509-57

Sepahvand E, Ghasemnezhad M, Salvador A \& Khademi O (2013). Impact of 1-MCP and hot water treatment on postharvest quality of pomegranate fruit. Acta Horticulturae 1012: 1217-1222 10.17660/ActaHortic.2013.1012.163

TSI (2018) Crop production statistics (In Turkish). Retrieved in August 27, 2019 from www.tuik.gov.tr 